\title{
Knowledge, Attitudes, and Preventative Practices (KAPs) Towards COVID-19 Among International Students in China
}

This article was published in the following Dove Press journal: Infection and Drug Resistance

\author{
Xue-Lian Wu' \\ George N Chidimbah Munthali ${ }^{2}$ \\ 'School of Economics and Management, \\ Yangtze University, Jingzhou, Hubei, \\ People's Republic of China; ${ }^{2}$ Finance \\ Department, Mzuzu University, Luwinga \\ Malawi; Chidimbah Research Centre, \\ Mzuzu, Malawi
}

Purpose: The study aimed to find out about the knowledge, attitudes, and preventative practices of COVID-19 among international students in China during the pandemic.

Material and Methods: A cross-section survey was conducted among 300 international students from 13 different universities in Hubei province of China between March and April 2020 which relied upon convenience sampling method.

Results: Out of 300 respondents, 153 (51\%) of the respondents were female students, of which the majority were single, undergraduate students who were doing medicine $(163,54.3 \%)$ and engineering programs $(68,22.7 \%)$. The majority of international students had an impressive knowledge on the causes, risks, and spread of COVID-19, and that they were no misconception of the pandemic $229(76 \%)$ to 281 (98\%) respectively. These students also demonstrated a markedly positive attitude towards the virus and a feeling that they were almost completely safe being in China $(264,84 \%)$. Variations were found on Knowledge scores in age group $(P<0.01)$ and majors $(P=0.025)$, attitude scores on major of study $(P=0.015)$, and experience $(P<0.01)$. Furthermore, the results revealed that all the students $(300,100 \%)$ adhered to and practiced set preventive measures against COVID-19 and that there was a positive correlation between attitudes and preventative practices $(\mathrm{r}=0.219, P<0.01)$.

Conclusion: This study found that social media platform was contributing enormously towards information dissemination and Chinese universities were commended for their continuous notifications on COVID-19 which helped students to have full knowledge. This, in turn, was instrumental in helping students to form good attitudes and practices towards COVID-19.

Keywords: coronavirus disease 2019 (COVID-19), pandemics, prevention and control, knowledge, attitudes, perception, international students

\section{Introduction}

In late December 2019 in Wuhan City, Hubei Province of People Republic of China, recorded the first case of pneumonia known as 2019nCoV (now COVID-19) was reported, with a trace of a seafood market. Little did the world know that was just the beginning of the deadly viral disease and it would later bring the whole world to a halt. ${ }^{1-3}$ The disease proved later to be highly contagious and traveled to the rest of the world at warp speed. On January 13, 2020, the first imported case was also reported in Thailand and after that cases were reported in Japan and many other countries. It soon became apparent to the world that COVID-19 was a global public health threat and it prompted the World Health
Correspondence: George N Chidimbah Munthali

Finance Department, Mzuzu University, Luwinga Malawi; Chidimbah Research

Centre, Area Code: 07I6, Mzuzu, Malawi

Tel +265884 135892

Email ndazionaacca@yahoo.com
Infection and Drug Resistance 2021:14 507-518 
Organization (WHO) to swiftly move in and declare COVID-19 as a global pandemic on March 11, 2020. ${ }^{4-7}$ COVID-19 is in a group of zoonotic viruses that can be transmitted through human and animal contacts, and these respiratory viruses cause severe acute respiratory syndrome (SARS), with symptoms of fever and coughing, which had caused close to 1,690,061 human deaths across the world and the total affected patients had increased to more than $75,704,857$ as of December 22, $2020^{8}$.

Many scholars have explained extensively on epidemics and pandemics as it is the subject area that affects the survival of human life which is the utmost resource in any development endeavor. In their studies, they have sought to place interest in variables of knowledge, attitudes, and practices (KAPs) of specific epidemics or pandemic. Some explained the KAPs on HIV/AIDS and its prevention, ${ }^{9-12}$ others dwelt on KAPs on Cholera and its prevention, ${ }^{13-15}$ some focused on KAPs on Ebola and prevention, ${ }^{16,17}$ and others focused on KAPs on SARS, N1H1, and their prevention, ${ }^{18-20}$ with not much current research on KAPs on COVID-19. ${ }^{6,21}$ While there is huge literature on the KAPs of different kinds of pandemics, literature about the KAPs of specific pandemics on foreign students in other countries is limited. Consequently, most of the studies were conducted on native students on campuses of colleges and universities ${ }^{10,11,22}$ which may be different than for foreign students. Some researchers found that there is a percentage of risk associated with the status of a person, especially migrants and foreigners resident in other countries other than their own. ${ }^{23,24}$ Therefore, in view of political, social, geographical, and other factors that converge in China, this research sought to bridge the existing gap in the literature on the KAPs of COVID-19 among international students, especially with this current pandemic of COVID-19 which has brought the whole world to a virtual standstill, a scenario that has never happened before in recent history. The main aim of this study was to find out the KAPs of COVID-19 among international students' resident in China at the time of the pandemic, and specific objectives were i) to find out knowledge about COVID-19 among international students' resident in China, ii) to analyze the formed attitudes of the international students towards COVID-19, iii) for investigation if the international students are abiding by and practising preventative practices to steer clear of the COVID-19 pandemic, and iv) to analyze the relationship between knowledge, attitudes, and preventative measures of the COVID-19.

\section{Materials and Methods}

\section{Study Design and Setting}

This cross-sectional study was carried out during March and April, 2020 among international students in 13 universities of Hubei Province, China. Further, this study applied a quantitative research methodology. China is among the leading countries in the world that recently had lured throngs of international students from across the globe to come and enrol at some of its prestigious colleges and universities. ${ }^{25}$ There are a number of reasons for the affinity that China continued to enjoy from foreign students. Some of these included the deliberate initiatives put in place by the Chinese government by offering generous academic scholarships to students for different nationalities. These scholarships are of different kinds and are in perfect sync with China's quest to claim a stake of clout in global affairs and further advance its bosom national interests in the promotion of peace, trade, and corporation like Belt and Road Initiative. ${ }^{26}$ While many students benefited from such initiatives, there are also droves of students that catered for their study expenses in China under selfsponsored programs which are in many ways made possible, such as low cost of tuition fee, living standards and programexpertise as compared to other countries in the world. Hubei is located in the central part of the People's Republic of China, which is mostly known for its agricultural activities that are done within the Yangtze river, manufacturing activities, its transportation, and communication hub of Wuhan, and also with a lot of institutions of higher learning that offer graduate and post-graduate programs to both natives and international students. ${ }^{27,28}$ This area was selected because it is where the virus started and that it has been hit mostly by it. According to the Ministry of Education in China (MOE), Hubei is among the top ten provinces in China with the highest number of international students, with more than 21,371 as of April 19, 2019, with the Asian continent dominating, with 59.95\%, seconded by Africa, at $16.97 \%{ }^{28}$

\section{Population and Sampling}

The study targeted all undergraduate and postgraduate international students who were present in China during the outbreak, but not including those who went back home due to holiday and their embassy evacuation processes. This study used convenience sampling to select 13 universities in Hubei province due to easy access and the epicenter province of COVID-19. Due to the fact that 
many students were evacuated to their countries and others were on holiday at the study time, furthermore, we used this technique with an aim of easy access of collecting data from the students after the identification. The universities that participated in this study were: Central China Normal University, China Three Gorges University, China University of Geoscience, Huazhong Agricultural University, Huazhong University of Science and Technology, Hubei University of Economics, Jianghan University, Jingchu University of Technology, SouthCentral University for Nationalities, Wuhan Institute of Technology, Wuhan Textile University, Wuhan University of Technology, and Yangtze University.

The data for this study was collected through a prepared standard questionnaire, which was sent through online means to identified leaders of international students in universities on a voluntarily basis. A total number of 392 respondents were targeted after calculating the sample size with a formula used by Yamane (1967: 886) with 95\% confidence level and $P=0.05$ level of precision. ${ }^{29}$

$$
x=\frac{N}{1+\mathrm{N}(e) 2}{ }^{29}
$$

Where $\mathrm{n}$ is the sample size, $\mathrm{N}=(21,371)$ is the population size, and $\mathrm{e}=0.05$ is the level of precision.

In this study, we used a single online Microsoft link that was shared with social media groups in identified universities. As such, there was no exact number of respondents that were enrolled, but we only targeted the specific number of 392 respondents by using the sample size calculator. Further, due to confidentiality purposes we did not gather the names of the respondents or from which area there were from, as long as they were from the selected universities.

\section{Development of an Instrument}

The questionnaire prepared open ended and closed ended questions that captured qualitative and quantitative data. The questionnaire was grouped into four parts, ie, knowledge, attitude, practices, and social demographic characteristics. A nominal scale of yes or no questions was applied in all sections of knowledge, attitude, and preventative practices, while on social demographic data respondents were given a choice to select the right one depending to their group or category. On scores of the knowledge, attitude, and preventative practices, each correct answer was assigned one point (good knowledge, positive attitude, and usage of preventative practice); incorrect answers or unknown answers were assigned 0 points (poor knowledge, misconception, negative attitude, and absence of not using preventative practices). A participant could receive a total knowledge score ranging from 0-12; higher scores indicate better knowledge of COVID-19.

\section{Validation and Pilot Study}

We conducted a pilot study to assess the validity and reliability of the instrument before conducting the final survey. We involved three experts in this area of study, one from University of Abeokuta in Nigeria, one from University in Bangladesh, and the other from Yangtze University who helped to assess the items in the questionnaires to see if they were relevant and could correctly measure the knowledge, attitude, and preventive practice of international students in China. All comments were corrected. After that, we a conducted a Pilot study involving 30 international students at Yangtze University. The data collected results showed internal reliability (with Cronbach's alpha=0.62).

\section{Data Analysis Tools}

After collecting all data through the online Microsoft forms system, it was downloaded and coded into excel and imported into the software IMB SPSS Version 23 where analysis was carried out. Descriptions were used to present frequencies, means scores, and standard deviations. One-way ANOVA, Pearson correlation, and Binary Logistic were used for analysis of associations, with statistical significance being put at 0.05 (two-tailed). The study employed a linear regression model output obtained using the backward likelihood ratio.

\section{Ethical Consideration}

This study followed the guidelines laid down in the Helsinki Declaration, and approval of this study went through the Yangtze University International Student Office (ISO) responsible for research ethics (Approval Ref number: REF/YU/2020/07). Personal consent was requested from all the respondents who participated in the survey and, as such, this survey was conducted on a voluntary basis and no participant was coerced to provide the information with which to furnish the findings of the study. They were further assured that all information obtained would be solely used for the publication of the study with high level of confidentiality of the data, and that names of students would not be indicated in any way unless the owners consented to it or that a request was made by them to have their names published as well. 


\section{Results}

\section{Social Demographic Characteristics of}

\section{Respondents}

The survey targeted 392 respondents. However, information was collected from only 300 respondents through the administered online questionnaires. In terms of response percentage, that stood at an about $76.5 \%$ response rate, of which $\mathrm{N}=153$ (51\%) were female and $\mathrm{N}=147$ (49\%) male. On marital status, the majority the respondents $(\mathrm{N}=279$, 93\%) were single, out of which 258 (86\%) belonged to the age group of 20-30 years, 237 (79\%) of them were pursuing undergraduate studies, of which $163(54.3 \%)$ were doing a medicine-related program, followed by 68 (22.7\%) who were doing engineering courses. Moreover, 192 (64\%) of the respondents indicated that they had been staying in China for more than 2 years, and lastly on religion affiliation, $155(51 \%)$ of them were Christians, followed by 111 (27.1\%) who were Muslims (Table 1).

\section{Sources of Information About COVID-19 Disease Control and Preventative Measures}

The respondents were asked about the main source of information for COVID-19 disease control and preventative measures. The results indicate that the majority of them extracted information from the Internet (211, 70.3\%), followed by school notifications (75, 25\%) (Table 2).

\section{Knowledge About COVID-19 Disease Control and Preventative Measures}

Table 3 shows the results regarding knowledge about COVID-19. The results show that the majority of the students reveal above the average of $50 \%$ which is given as the baseline for good knowledge by assessing the causes. Furthermore, results indicate that the vast majority $(288,96 \%)$ of the respondents had knowledge about the COVID-19 mode of spread, with 288 (96\%) indicating their awareness of it being a highly contagious disease, $281(93.7 \%)$ aware of the potentially fatal risks associated with COVID-19, 288 (96\%) showing knowledge about the symptoms of COVID19 , and $270(90 \%)$ demonstrating that they held no misconceptions of COVID-19 (Table 3).
Table I Socio-Demographic Characteristics of the Respondents (International Students) in Chinese Universities in the Month of March-April $2020(\mathrm{~N}=300)$

\begin{tabular}{|c|c|c|c|}
\hline $\begin{array}{l}\text { Independent } \\
\text { Variables }\end{array}$ & Category & Frequency & $\begin{array}{l}\text { Percent } \\
\text { (\%) }\end{array}$ \\
\hline Gender & $\begin{array}{l}\text { Male } \\
\text { Female }\end{array}$ & $\begin{array}{l}147 \\
153\end{array}$ & $\begin{array}{l}49.0 \\
51.0 *\end{array}$ \\
\hline Age Group & $\begin{array}{l}<20 \\
20-30 \\
30+\end{array}$ & $\begin{array}{l}19 \\
258 \\
23\end{array}$ & $\begin{array}{l}6.3 \\
86.0 * \\
7.7\end{array}$ \\
\hline Marital Status & $\begin{array}{l}\text { Single } \\
\text { Married } \\
\text { Others }\end{array}$ & $\begin{array}{l}279 \\
12 \\
9\end{array}$ & $\begin{array}{l}93.0 * \\
4.0 \\
3.0\end{array}$ \\
\hline Level of Program & $\begin{array}{l}\text { Undergraduate } \\
\text { Postgraduate }\end{array}$ & $\begin{array}{l}237 \\
63\end{array}$ & $\begin{array}{l}79.0 * \\
21.0\end{array}$ \\
\hline Major & $\begin{array}{l}\text { Medical Related } \\
\text { Programs } \\
\text { Engineering Related } \\
\text { Programs } \\
\text { Agriculture Related } \\
\text { Program } \\
\text { Business Related } \\
\text { Program } \\
\text { Others }\end{array}$ & $\begin{array}{l}163 \\
68 \\
21 \\
26 \\
22\end{array}$ & $\begin{array}{l}54.3^{*} \\
22.7 \\
7.0 \\
8.7 \\
7.3\end{array}$ \\
\hline Experience & $\begin{array}{l}<1 \\
1-2 \\
2+\end{array}$ & $\begin{array}{l}57 \\
51 \\
192\end{array}$ & $\begin{array}{l}19.0 \\
17.0 \\
64.0 *\end{array}$ \\
\hline $\begin{array}{l}\text { Religion } \\
\text { Affiliation }\end{array}$ & $\begin{array}{l}\text { Islam } \\
\text { Christian } \\
\text { Buddhist } \\
\text { Hinduism } \\
\text { Do not want to } \\
\text { disclose } \\
\text { Others }\end{array}$ & $\begin{array}{l}111 \\
155 \\
6 \\
4 \\
19 \\
5\end{array}$ & $\begin{array}{l}37.0 \\
51.7^{*} \\
2.0 \\
1.3 \\
6.3 \\
1.7\end{array}$ \\
\hline
\end{tabular}

Notes: *Statistical significance that is above the average level of $50 \%$.

\section{Misconceptions About COVID-19 Disease Control and Preventative Measures}

While answering the questions asked to assess their misconception towards COVID-19, the results indicated that the majority had no misconceptions, as the results were also all above $50 \%$, answering Yes and No where necessary, which was acting as a baseline with reference to World Health Oganization guidelines as follows; 217 (72\%) the virus can be killed by the sun, $270(90 \%)$ the virus can be killed by drinking alcohol, $240(80 \%)$ the virus cannot infect young people, $246(82 \%)$ the virus cannot kill people with special 
Table 2 Results on the Sources of COVID-19 Information Amongst Respondents $(\mathrm{N}=300)$

\begin{tabular}{|l|l|l|}
\hline Source of Information & Frequency & Percent (\%) \\
\hline Internet Platforms & 211 & $70.3^{* *}$ \\
School Notification & 75 & $25.0^{*}$ \\
Wires, TV, and Radio & 7 & 2.3 \\
Family and Friends & 3 & 1.0 \\
Others Means & 4 & 1.3 \\
\hline
\end{tabular}

Notes: *Significant level at $25 \%$; **Highest level of significance of the results, which is above $50 \%$ level.

genes, and $187(62.3 \%)$ that indeed the virus can contaminate the atmosphere air (Table 4).

\section{Attitude and Perception Towards COVID-19 Disease Control and}

\section{Preventative Measures}

Results about respondents' attitudes towards COVID-19 are illustrated in Table 5. The results were calculated as above $50 \%$, which was set as the baseline of positive attitude. This shows that the majority of the respondents (ie, 195, 65\%) disagreed with the conception that "COVID-19" is a punishment from God, while $240(80 \%)$ of them also stated that COVID-19 could be associated with any person. Furthermore, after being asked about their safety perceptions, the majority (ie, 264, 80\%) believed that it is safe to stay in China despite the outbreak.

\section{Practices of COVID-19 Disease Preventative Measures}

In Table 6 , the preventive practices applied by respondents which were announced by the government or authorities are revealed. The results show that the majority of the respondents keenly followed all the set preventive practices, as many scores were above $50 \%$ which was the baseline for practices to be followed in this study. Moreover, results indicate that $100(100 \%)$ respondents use obligatory face masks when doing outdoor activities, while $256(85.3 \%)$ did not allow visitors in their university dormitories. It was found that 299 (99.7\%) were washing their hands frequently and $282(94 \%)$ did not touch their faces with hands when they were dirty. The results indicate that 287 (95.7\%) avoided going out and kept a distance of 3 meters from anyone.

Table 3 Results from Respondents About Their Knowledge Towards COVID-I9 Pandemic (N=300)

\begin{tabular}{|c|c|c|c|c|c|}
\hline & Knowledge Questions & Yes (F) & Yes (\%) & No (F) & No (\%) \\
\hline I & Do you know that COVID-19 is an infectious disease? & 288 & $96 *$ & 12 & 4 \\
\hline 2 & $\begin{array}{l}\text { Do you know that COVID-19 is a zoonotic pathogen virus which can spread from animals to humans through } \\
\text { contact? }\end{array}$ & 223 & $74.3 *$ & 77 & 25.7 \\
\hline 3 & $\begin{array}{l}\text { Do you know that COVID-19 could spread through cough and sneezes, or from touching an object that has been } \\
\text { contaminated with the virus? }\end{array}$ & 294 & $98^{*}$ & 6 & 2 \\
\hline 4 & $\begin{array}{l}\text { Do you know that there is a risk if you recently traveled from an area with an ongoing spread of COVID-19 as } \\
\text { determined by WHO? }\end{array}$ & 281 & $93.7 *$ & 19 & 6.3 \\
\hline 5 & $\begin{array}{l}\text { Do you know that you are at risk if you had close contact with someone who has COVID-19 virus, such as } \\
\text { a classmate? }\end{array}$ & 260 & $86.7^{*}$ & 40 & 13.3 \\
\hline 6 & $\begin{array}{l}\text { Do you know that you are at risk if you had close contact with someone who had COVID-19 virus such as teachers } \\
\text { and anyone who has been taking care of the infected person? }\end{array}$ & 260 & $86.7 *$ & 40 & 13.3 \\
\hline 7 & $\begin{array}{l}\text { Do you know that there are risks to anyone who has chronical underlying healthy conditions like diabetes, high } \\
\text { blood pressure, heart and lung diseases? }\end{array}$ & 249 & $83^{*}$ & 51 & 17 \\
\hline 8 & Do you know this symptom of COVID-19 - Fever? & 288 & $96 *$ & 12 & 4 \\
\hline 9 & Do you know this symptom of COVID-19 - Cough? & 288 & $96^{*}$ & 12 & 4 \\
\hline 10 & Do you know this symptom of COVID-19 - -Difficulty in Breathing? & 287 & $95.7 *$ & 13 & 4.3 \\
\hline II & Do you know this symptom of COVID-19 - Tiredness & 266 & $88.7 *$ & 34 & 11.3 \\
\hline 12 & Do you know this symptom of COVID-19 - Running Nose? & 229 & $76.3 *$ & 71 & 23.7 \\
\hline 13 & Do You know this symptom of COVID-19 - Sore Throat? & 263 & $87.7^{*}$ & 37 & 12.3 \\
\hline
\end{tabular}

Notes: *Percentages (\%) of good Knowledge level from the respondents which is set to be of significance at above the average level of $50 \%$. 
Table 4 Misconception Results Towards COVID-19 from the Respondents ( $N=300)$

\begin{tabular}{|c|c|c|c|c|c|}
\hline & Statement & Yes (F) & Yes (\%) & No (F) & No (\%) \\
\hline I & Do you think COVID-19 can be killed by staying in the sun? & 83 & 27.7 & 217 & $72.3^{*}$ \\
\hline 2 & Do you think COVID-19 can be killed by drinking a lot of alcohol or beer? & 30 & 10 & $270 *$ & $90^{*}$ \\
\hline 3 & Do you think COVID-19 cannot kill young people? & 60 & 20 & 240 & $80 *$ \\
\hline 4 & Do you think COVID-19 cannot kill other people because they have special genes? & 54 & 18 & 246 & $82 *$ \\
\hline 8 & Do you think COVID-19 can contaminate atmosphere air? & 187 & $62.3^{*}$ & 113 & 37.7 \\
\hline
\end{tabular}

Notes: *Percentages (\%) that are of significance with good attitudes levels without misconception from the respondents, which is above the average level of $50 \%$.

Table 5 Attitudes of Respondents Towards COVID-19 ( $N=300)$

\begin{tabular}{|l|l|l|l|l|l|}
\hline & Statement & Yes (F) & Yes (\%) & No (F) & No (\%) \\
\hline I & It was a punishment from God & 105 & 35 & 195 & $65 *$ \\
2 & It was a disease associated with other people not me & 60 & 20 & 240 & $80 *$ \\
3 & Do you still feel safe here in China after the outbreak of COVID-19 & 264 & $88^{*}$ & 36 & 12 \\
\hline
\end{tabular}

Notes: *Percentages (\%) of good attitudes levels from the respondents that is significant, which is above the average level of $50 \%$.

Table 6 Preventative Practices by Students $(\mathrm{N}=300)$

\begin{tabular}{|l|l|l|l|l|l|}
\hline & Statement & Yes (F) & Yes (\%) & No (F) & No (\%) \\
\hline 1 & Wearing mask when going out & 300 & $100^{*}$ & 0 & 0 \\
2 & No visitors entertaining in dormitory & 256 & $85.3^{*}$ & 44 & 14.7 \\
3 & Washing hands frequently with soaps & 299 & $99.7^{*}$ & 1 & 18 \\
4 & Do not touch your face, eyes, and nose when hands are dirty & 282 & $94^{*}$ & 6.3 \\
5 & Do not go out if you are feeling sick or having any symptoms & 287 & $95.7^{*}$ & 13 & 13 \\
6 & Keeping a distance of 3 feet away from anyone & 287 & $95.7^{*}$ & 13 & 4.3 \\
\hline
\end{tabular}

Notes: *Percentages (\%) of good preventative practices from the respondents which is above the average level of $50 \%$.

\section{Univariate and Bivariate Analysis Knowledge and Practices Scores}

The questionnaire prepared had 13 questions for knowledge, five for misconceptions, three for attitude, and six for preventative practices, and each question used dummy variables, scoring 1 for an individual with good knowledge and 0 for an individual with poor knowledge (score $=1$ for individual non-misconception, and 0 for individual misconception), with total knowledge scores $=$ all knowledge + all not misconception, for attitude score $=1$ for good attitude and 0 for negative attitude, and lastly for preventive practices score $=1$ for good preventative practices and 0 for bad practices. Correlation between knowledge and practice scores was found to be insignificant.

On the distribution of knowledge and practices scores, the results reveal that the mean knowledge scores vary significantly across age group $(P<0.01)$ and major of study $(P=0.025)$, while the mean scores of the practices varies significantly between the major of study $(P=0.015)$ and experience $(P<0.01)$, while there are no significance variations in attitude means scores (Table 7).
According to the linear regression analysis, after converting the independent variables into binary form, the results show that age group of $<20$ (vs Other converts, $\beta=-1.635$; $P<0.01$ ), major convert 2 of Engineering (vs other converts, $\beta=-0.956 ; P<0.01$ ), major convert 5 of others (vs other converts, $\beta=-.1 .200 ; P=0.018)$ and religion convert 1 of Islam (vs other convert 2 of Christianity, $\beta=-0.559$; $P=0.040$ ) are significantly associated with lower knowledge scores. On the other hand, major convert 2 of Engineering (vs other converts, $\beta=0.265 ; P=0.012$ ), Experience Convert 1 of $<1$ (vs other converts, $\beta=0.449 ; P<0.01$ ), and religion convert 1 of Islam (vs other converts, $\beta=0.248 ; P<0.01$ ) are significantly associated with high practice scores (Tables 8 and 9 ).

\section{Relationships Between Dependent Variables}

In Table 10, results of the Pearson correlation are revealed and it shows that there is a positive correlation between attitude mean scores and preventative practice mean scores of COVID-19 ( $\mathrm{r}=0.219, P<0.01)$, which simply illustrates 
Table 7 Distribution of Knowledge and Preventive Practice Scores Among International Students in China

\begin{tabular}{|c|c|c|c|c|c|c|c|c|c|}
\hline Characteristics & $\begin{array}{l}\text { Knowledge } \\
\text { Score } \pm S D\end{array}$ & F-value & $P$-value & $\begin{array}{l}\text { Attitude } \\
\text { Score } \pm S D\end{array}$ & F-value & $P$-value & $\begin{array}{l}\text { Practice } \\
\text { Score } \pm S D\end{array}$ & F-value & $P$-value \\
\hline $\begin{array}{c}\text { Gender } \\
\text { Male } \\
\text { Female }\end{array}$ & $\begin{array}{l}15.23 \pm 2.27 \\
14.94 \pm 2.25\end{array}$ & 1.24 & 0.267 & $\begin{array}{l}2.33 \pm 0.66 \\
2.33 \pm 0.72\end{array}$ & 0.07 & $0.093^{*}$ & $\begin{array}{l}7.61 \pm 0.68 \\
7.46 \pm 0.87\end{array}$ & 2.67 & 0.103 \\
\hline $\begin{array}{l}\text { Age group } \\
\begin{array}{l}<20 \\
20-30 \\
30+\end{array}\end{array}$ & $\begin{array}{l}\mid 3.63 \pm 3.82 \\
|5.12 \pm 2.1| \\
|5.9| \pm 1.68\end{array}$ & 5.67 & $0.004 * *$ & $\begin{array}{l}2.47 \pm 0.5 I \\
2.3 I \pm 0.7 I \\
2.39 \pm 0.58\end{array}$ & 0.57 & 0.566 & $\begin{array}{l}7.42 \pm 0.77 \\
7.55 \pm 0.77 \\
7.39 \pm 0.99\end{array}$ & 0.63 & 0.536 \\
\hline $\begin{array}{l}\text { Marital status } \\
\text { Single } \\
\text { Married } \\
\text { Divorced } \\
\text { Others }\end{array}$ & $\begin{array}{l}15.01 \pm 2.30 \\
16.17 \pm 1.02 \\
15.89 \pm 1.69\end{array}$ & 2.11 & 0.123 & $\begin{array}{l}2.32 \pm 0.68 \\
2.4 I \pm 0.90 \\
2.22 \pm 0.83\end{array}$ & $0.203^{\prime}$ & 0.816 & $\begin{array}{l}7.51 \pm 0.80 \\
7.67 \pm 0.49 \\
7.78 \pm 0.44\end{array}$ & 0.671 & 0.512 \\
\hline $\begin{array}{l}\text { Level of } \\
\text { program } \\
\text { Undergraduate } \\
\text { Postgraduate }\end{array}$ & $\begin{array}{l}14.97 \pm 2.27 \\
15.52 \pm 2.16\end{array}$ & 3.051 & $0.082 *$ & $\begin{array}{l}2.34 \pm 0.65 \\
2.20 \pm 0.83\end{array}$ & 0.328 & 0.567 & $\begin{array}{l}7.5 I \pm 0.76 \\
7.57 \pm 0.86\end{array}$ & 0.221 & 0.639 \\
\hline $\begin{array}{l}\text { Major } \\
\text { Medical } \\
\text { Engineering } \\
\text { Agriculture } \\
\text { Business } \\
\text { Others }\end{array}$ & $\begin{array}{l}15.28 \pm 2.06 \\
14.56 \pm 2.54 \\
15.81 \pm 1.86 \\
15.38 \pm 2.56 \\
\mid 4.18 \pm 2.38\end{array}$ & 2.832 & $0.025^{* *}$ & $\begin{array}{l}2.3 I \pm 0.67 \\
2.4 I \pm 0.67 \\
2.24 \pm 0.88 \\
2.26 \pm 0.67 \\
2.36 \pm 0.72\end{array}$ & 0.412 & 0.796 & $\begin{array}{l}7.48 \pm 0.78 \\
7.74 \pm 0.56 \\
7.76 \pm 0.43 \\
7.19 \pm 1.05 \\
7.45 \pm 1.05\end{array}$ & 3.128 & $0.015^{* *}$ \\
\hline $\begin{array}{l}\text { Experience } \\
\quad<1 \\
1-2 \\
2+\end{array}$ & $\begin{array}{l}\mid 5.16 \pm 2.29 \\
\mid 5.57 \pm 2.40 \\
|4.93 \pm 2.2|\end{array}$ & 1.643 & 0.195 & $\begin{array}{l}2.47 \pm 0.68 \\
2.25 \pm 0.62 \\
2.30 \pm 0.70\end{array}$ & 1.65 & 0.195 & $\begin{array}{l}7.84 \pm 0.37 \\
7.47 \pm 0.75 \\
7.45 \pm 0.86\end{array}$ & 5.733 & $0.004^{* *}$ \\
\hline $\begin{array}{l}\text { Religion } \\
\text { Islam } \\
\text { Christian } \\
\text { Buddhist } \\
\text { Hindu } \\
\text { Do not want to } \\
\text { disclose } \\
\text { Others }\end{array}$ & $\begin{array}{l}\mid 4.83 \pm 2.56 \\
|5.44 \pm| .96 \\
|4.00 \pm| .26 \\
\mid 3.75 \pm 2.06 \\
\mid 4.32 \pm 2.66 \\
|4.80 \pm| .30\end{array}$ & 2.124 & $0.063 *$ & $\begin{array}{l}2.25 \pm 0.65 \\
2.34 \pm 0.69 \\
2.50 \pm 0.54 \\
2.25 \pm 0.50 \\
2.63 \pm 0.68 \\
2.20 \pm 0.44\end{array}$ & 1.152 & 0.333 & $\begin{array}{l}7.64 \pm 0.61 \\
7.43 \pm 0.93 \\
7.67 \pm 0.52 \\
7.50 \pm 0.58 \\
7.73 \pm 0.45 \\
7.20 \pm 0.44\end{array}$ & 1.397 & 0.225 \\
\hline
\end{tabular}

Notes: *Significant at the 0.1 level, and **Significant at the 0.05 level.

Abbreviation: SD, standard deviation.

that the higher the positive attitude, the higher the better preventative practices, and the lower the good attitude, the lower the preventative practice of COVID-19,. This simply illustrates that the possession of a positive attitude would definitely increase the preventative practices of COVID-19, which fulfils the hypothesis of the study.

\section{Discussion}

The present study illustrates through the social demographic characteristics that it had almost equal gender participation, female $51 \%$ with only $1 \%$ percentage high as compared to $49 \%$ female. However, we cannot conclude that there is a growing participation of males in social science studies with the reason that the presence of male students at the time of the survey was more, as many studies on a similar topic have proved to have more female participation with a huge gap of leading as compared to the one found in our study. ${ }^{15,30-33}$ Furthermore, it is found that the majority of international students were young, single, and they were doing either medicine or 
Table 8 Linear Regression Model Output Obtained Using the Backward Likelihood Ratio Method for Knowledge Scores

\begin{tabular}{|l|l|l|l|l|}
\hline Convert & $\boldsymbol{\beta}$ & Std. Error & t & Sig. \\
\hline Intercept & 15.586 & 0.206 & 75.690 & 0.000 \\
Age First Convert (<20) & -1.635 & 0.526 & -3.108 & $0.002^{* *}$ \\
Age Third Convert (30+) & 0.831 & 0.482 & 1.723 & $0.086^{*}$ \\
Marital Converted 4 (Others) & 1.244 & 0.747 & 1.667 & $0.097 *$ \\
Major Converted 2 (Engin.) & -.956 & 0.306 & -3.119 & $0.002^{* *}$ \\
Major Converted 5 (other) & -1.200 & 0.503 & -2.385 & $0.018^{* *}$ \\
Experience Converted 2 (I-2) & 0.570 & 0.335 & 1.704 & $0.089 *$ \\
Religion Converted I (Islam) & -.559 & 0.270 & -2.067 & $0.040^{* *}$ \\
Religion Converted 4 (Buddhi) & -1.836 & 1.096 & -1.674 & $0.095 *$ \\
Religion Converted 5 (D.W.D) & -.959 & 0.526 & -1.824 & $0.069 *$ \\
\hline
\end{tabular}

Notes: *Significant at the 0.1 level, and **Significant at the 0.05 level.

Abbreviation: D.W.D, do not want to disclose.

Table 9 Linear Regression Model Output Obtained Using the Backward Likelihood Ratio Method for Practice Scores

\begin{tabular}{|l|l|l|l|l|}
\hline Convert & $\boldsymbol{\beta}$ & Std. Error & t & Sig. \\
\hline Intercept & 7.271 & 0.068 & 106.856 & 0.000 \\
Major Converted 2 (Engin.) & 0.265 & 0.105 & 2.530 & $0.012^{* *}$ \\
Experience Converted I (<I) & 0.449 & 0.113 & 3.979 & $0.000^{* *}$ \\
Religion Converted I (Islam) & 0.248 & 0.093 & 2.669 & $0.008^{* *}$ \\
Religion Converted 5 (D.W.D) & 0.345 & 0.185 & 1.865 & $0.063 *$ \\
\hline
\end{tabular}

Notes: *Significant at the 0.1 level, and **Significant at the 0.05 level.

Abbreviation: D.W.D, do not want to disclose.

Table 10 Relationships Between Attitude, Knowledge and Preventative Practices of COVID-I9

\begin{tabular}{|c|c|c|c|c|}
\hline \multicolumn{2}{|c|}{ Dependent Variables } & \multirow{2}{*}{ Knowledge Scores } & \multirow{2}{*}{$\begin{array}{l}\text { Attitude Scores } \\
0.014 \\
0.803\end{array}$} & \multirow{2}{*}{$\begin{array}{l}\text { Practice Scores } \\
0.048 \\
0.403\end{array}$} \\
\hline Knowledge Score & $\begin{array}{l}\text { Pearson Correlation } \\
\text { Sig. (2-tailed) }\end{array}$ & & & \\
\hline Attitude Score & $\begin{array}{l}\text { Pearson Correlation } \\
\text { Sig. (2-tailed) }\end{array}$ & $\begin{array}{l}0.014 \\
0.803\end{array}$ & 1 & $\begin{array}{l}0.219 \\
0.000 * *\end{array}$ \\
\hline Practice Score & $\begin{array}{l}\text { Pearson Correlation } \\
\text { Sig. (2-tailed) }\end{array}$ & $\begin{array}{l}0.048 \\
0.403\end{array}$ & $\begin{array}{l}0.219 \\
0.000 * *\end{array}$ & 1 \\
\hline
\end{tabular}

Note: **Significant at the 0.01 level (2-tailed).

engineering-related programs, something that mainly contributed to their protracted stay of more than 2 years, as many of these courses are up to 5 years before graduating. About studying in China, there are a lot of reasons behind the attraction of the two aforementioned courses, the main of which was that many Chinese universities are highly equipped with the state of the art technologies aptly positioned to provide the best training in the medical and engineering courses and also the affordability of academic expenses in China as compared to other countries. ${ }^{34}$ The presence of many students of the age group of 20 years below in universities is also a good indication that the youth are able to attain a higher level of academics while at a tender age. Furthermore, the research also revealed that many international students belonged to religious affiliations, with Christianity and Islam being the two major religious groupings, with a lot of member affiliates. This simply indicates that many international students, despite being in a foreign land, were able to express their religious affiliation.

Throughout their academic studies, scholars have laid emphasis on the fact that knowledge is exceedingly important as it has a direct bearing on the attitude that people form towards something. ${ }^{6,31,35}$ The findings of the study 
corroborated the foreboding fact and further found that international students had enough and adequate information which positively increased their good knowledge regarding the causes, spread, and symptoms of COVID19 , with have high scores of up to $98 \%$. However, the results indicated that there was a significant mean score difference between age groups $(P<0.01)$, of which the group of $<20$ years had lower mean scores as compared to other groups, and major of study $(P=0.015)$, where those in engineering majors and other studies had lower mean scores as compared to medical and agriculture majors. These noted knowledge gaps arose primarily because medical and agricultural majors' students might have had biological sciences knowledge which is linked to infectious and virus diseases prior to the pandemic, as it might also be in their curriculum of study and is related to their professions which would have positively given them an added advantage of having good knowledge. The general findings of good knowledge on COVID-19 of this study are in agreement with other results that were conducted on similar topics on COVID-19 in other countries like China, India, Bangladesh, Cameroon, Nigeria, and Turkey ${ }^{6,21,22,31,32,36,37}$ recently. Furthermore, on knowledge gaps, the study is in conformity with results in other areas where pandemics like Cholera, Ebola, Avian Influenza (H5N1), N1H1 Flu Virus, and COVID-19 knowledge were researched like Thailand, Ecuador, Ethiopia, and Nigeria where they also found that there were knowledge gaps among people depending on social demographic factors like academic background, sex, and age. $9,30,33,38$ This good knowledge among international students could be attributed to the fact of Information Communication Technology (ICT) development and the nature of COVID-19 because it had been the news that anyone talked about day in day out because of the utterly devastating impact that the pandemic had on every aspect of human life. Despite this, it still differs with other studies on COVID-19 that were conducted in Hong Kong ${ }^{39}$ and other pandemics like Cholera conducted in Bangladesh where they found that many people had poor knowledge of COVID-19 and Cholera, respectively. ${ }^{13}$ This improvement on knowledge gaps can be further explained due to the devastating impacts that COVID-19 has brought which is evidenced in everyday life, especially those social distance measures like lockdown has really made its awareness go viral. ${ }^{2}$

ICT has proved to be contributing immensely to all the sectors development through the way and speed information could be transferred from one person to another. The study found a similar pattern and revealed that the Internet, through social media platforms, was the main source of information the international students used to know about COVID-19, seconded by the school notifications, which universities in China usually issued to apprise them of COVID-19 updates either weekly or monthly depending on the need of the institutions. The advance in technology was credited with profoundly changing the way people got access to vital information because previously researches on pandemics had more scores on TV, Radios, and friends as channels of source of information. ${ }^{21}$ It was therefore not surprising that the majority of the international students did not have misconceptions on the truth and reality of the facts regarding COVID-19 because they had all the necessary information from the Internet and school notifications which were accurate and were timely provided as well.

Attitude towards pandemics has not been constant among different people depending on many social demographic factors. However, this study found that many international students had a positive attitude towards COVID-19 and that, despite the majority of them being religious, they also believed and perceived that COVID-19 was not a punishment from God, a clear contrast to other studies on pandemics like HIV/AIDs that found that many people regarded pandemics as signs of punishments from God due to the sins that people had committed, ${ }^{9,30}$ and recent KAPs studies on COVID-19 in countries like Nepal and Hong Kong where they found low positive attitudes. $^{39,40}$ However, the results were in agreement with recent studies done Nigeria, China, and India where they also found that many people had a positive attitude towards COVID-19 and Cholera believed that they would fight and win anytime. ${ }^{6,21,36}$ With regard to their views on safety, international students confidently indicated that they felt safe being in China despite the outbreak of COVID-19, which was also attributed to the measures that the authorities implemented to make sure foreigners living in China, including students, were guaranteed of their safety. ${ }^{24}$ It therefore indicated that international students saw COVID-19 as a global pandemic infectious disease that was normal like any other pandemics which was supposed to be taken with all human collaboration without looking at where it came from or associating it with a certain group of people.

In regards to preventative practices towards COVID19 , almost all of the international students, regardless of 
their gender, demonstrated that they were keeping good preventative practices of COVID-19, like wearing masks when going out, not allowing visitors in their dormitory, etc. This could be due to the reasons that they really understand the importance of practising them, but also we could not rule out that fact that some could be fearing punishment from the schools and other authorities under their universities and location. However, it was found in this study that there were significant variations between major of study and experience, having lower mean scores towards preventative practices of COVID-19. The reasons could be those in lower age group $(<20)$ not being in a good number in China and that those that had more than 2 years stay feeling not scared because of their experience of staying in China. It was clear then that many people practised good preventative practises of pandemics in many countries due to the negative consequences that they saw when they failed to conform to them. As a results this research is in agreement with other studies that found that a lot of people practice good preventive and control practices given by their authorities. $^{22,31,41}$

Furthermore, this study found that there was a positive correlation between attitude and adherence to preventative practices against COVID-19, which indicated that if people possessed good attitudes towards pandemics like COVID-19 they were more likely to conform to all the preventive measures against COVID-19. However, there was no significant relationship between knowledge and attitude and practices, which differs with other studies which were conducted on the same topic and other topics. ${ }^{6,31}$ These differences could have arisen due to other limitations that the study had undergone.

\section{Limitations}

This study also has the following limitations. Firstly, coming up with a good sample size, when this study was conducted it was a time when schools were closed and some students were on holiday, especially those that are from countries that surround China like the Asian continent, whose students usually go home for holiday. Secondly, some students from other continents were evacuated back to their countries by their respective embassies. However, this study was aimed at only targeting those students that were still in China at that time and were experiencing COVID-19 and not those that were at home, as such coming up with the actual sample size was a limitation because the exact number of the student population left was not clearly known due to the situation itself and the researcher used 2019 Ministry of Education data plus other assumptions to try to come up with the population remaining in China. Also, many students were unwilling to fill in and send the questionnaires as many were tired of COVID-19 related issues. On the other hand, this study did not receive any special funding to foster some of the activities that would need funds like motivating the people that were identified as leaders to help in collecting data in their respective universities. This was a difficult task as it was all seen as voluntary work without any motivation.

\section{Conclusion}

The pandemic COVID-19 has wrought indescribable damage to all sectors of development and disrupted many activities including education globally. For instance, it is found that due to COVID-19, students all over the world are unable to attend their classes physically. International students in China where COVID-19 emerged showed that they had all the vital knowledge of the deadly virus. These students stated that Internet and school notifications provided at their respective colleges and universities was their primary sources of information about the pandemic. Many students found positive attitudes towards COVID-19 and perceived themselves to be safe being in China in the midst of COVID-19, and the majority of them followed all the required preventative practices. Fighting against COVID-19 requires the all-out efforts of everyone. These international students in China also demonstrated their zeal to help in the fight against the pandemic by adhering to all the necessary preventative measures put in place in order to reduce the spread of COVID-19.

\section{Abbreviations}

COVID-19, Coronavirus disease 2019; SARS, Severe Acute Respiratory Syndrome; H1N1, Hemagglutinin Type 1 and Neuraminidase Type 1; HIV/AIDS, Human Immunodeficiency Virus/Acquired Immune Deficiency Syndrome; WHO, World Health Organization; KAPs, Knowledge Attitude and Practices; CDC, Center for Disease and Control; ISO, International Student Office.

\section{Data Sharing Statement}

All data and other materials are included in the manuscript but anything, apart from that available in the manuscript can be requested from the authors. 


\section{Ethics Approval and Consent to Participate}

This study went through the approval of Yangtze University International Student Office (ISO) responsible for research ethics (Approval Reference number REF/YU/ 2020/07). Personal consents were requested from all the respondents who participated in the survey and, as such, this survey was conducted on a voluntary basis and no participant was coerced to provide the information with which to furnish the findings of the study.

\section{Acknowledgment}

We would like to thank the Yangtze University Intentional Student Office and School of Economics and Management for the unwavering support they have rendered during the process of producing this paper. Secondly, we would like to thank Dr. Olutosin A. Otekunrin, Prof. Mohamed Rizwani, Abdur Rahman and John Mushani for their initial comments on the work. Further, we thank the journal for the remarks made which really improved the quality of the work. Lastly, we also thank the following students for the help with the data collection exercise and other motivational help: Gama Rivas Daru, Ayivi Yao, Amponsah Randy Kwaku, Jambo Eric, Natasha Isabel Mbiza, Madina Kurmanali, Chisomo Grace Hamusuku, Nsabimana Shema Damars, Sihalath Phutthana, Prisca Raphael Kalinga, Marie Josephine Njiezu Ngounou, and Mujib Wohol.

\section{Author Contributions}

All authors made a significant contribution to the work reported, whether that is in the conception, study design, execution, acquisition of data, analysis, and interpretation, or in all these areas; took part in drafting, revising, or critically reviewing the article; gave final approval of the version to be published; have agreed on the journal to which the article has been submitted; and agree to be accountable for all aspects of the work.

\section{Funding}

No funding was provided on this project.

\section{Disclosure}

The authors declare that they have no financial or nonfinancial competing interests.

\section{References}

1. Munthali GN, Xuelian W. The future of Tobacco Industry Amidst of COVID-19 -a case of Malawi Producing Country. Biomed J Sci Tech Res. 2020;27(5):21104-21109. doi:10.26717/BJSTR.2020.27.004566

2. Munthali C, George N, Xuelian W. COVID-19 lockdown measures on least developing economies in Africa-a case of Malawi economy. Tech Soc Sci J. 2020;7:295-301. doi:10.47577/tssj.v7i1.394

3. Amponsah R, Frimpong IA. Ghana in the face of COVID-19: economic impact of coronavirus (2019-NCOV) outbreak on Ghana. Open J Bus Manag. 2020;08(04):1404-1411. doi:10.4236/ ojbm.2020.84089

4. World Health Organization (WHO). Novel coronavirus (2019-NCoV) situation report - 121 January 2020. 2020.

5. Zhang L, Liu Y. Potential interventions for novel coronavirus in China: a systematic review. J Med Virol. 2020;92(5):479-490. doi: $10.1002 / j m v .25707$

6. Rahman A, Sathi NJ. Knowledge, attitude, and preventive practices toward COVID-19 among Bangladeshi internet users. Electron J Gen Med. 2020;17(5):em245. doi:10.29333/ejgm/8223

7. Munthali GNC, Xuelian W. Covid-19 outbreak on malawi perspective. Electron J Gen Med. 2020;17(4):em210. doi:10.29333/ejgm/7871

8. World Health Organization (WHO). WHO coronavirus disease (COVID-19) dashboard. WHO; Published 2020. Available from: https://covid19.who.int/. Accessed December 22, 2020.

9. Muoghalu CO, Jegede SA. Perception of HIV/AIDS among the Igbo of Anambra State, Nigeria. SAHARA-J J Soc Asp HIV/AIDS. 2013;10 (1):1-13. doi:10.1080/17290376.2013.807052

10. Nwabueze SA, Azuike EC, Ezenyeaku CA, et al. Perception of sexually transmitted infection-preventive measures among Senior Secondary School Students in Nnewi-North Local Government Area, Anambra State, Nigeria. Open J Prev Med. 2014;4 (9):708-716. doi:10.4236/ojpm.2014.49080

11. Pathrudu GB, Kumar Patnaik K, Geethanjali MP. Knowledge, attitude $\mathrm{s}$, and perceptions about hiv/aids in teenage students in a high preva lence district in india. $J$ Evid Based Med Healthc. 2015;2 (43):7695-7702. doi:10.18410/jebmh/2015/1039

12. Al-Naggar RA, Al-Jashamy K. Perception of undergraduate university students towards sexually transmitted diseases: a qualitative study. J Mens Health. 2011;8(S1):S87-S90. doi:10.1016/S18756867(11)60031-6

13. Wahed T, Kaukab SST, Saha NC, et al. Knowledge of, attitudes toward, and preventive practices relating to cholera and oral cholera vaccine among urban high-risk groups: findings of a cross-sectional study in Dhaka, Bangladesh. BMC Public Health. 2013;13(1):242. doi:10.1186/1471-2458-13-242

14. Amaah P. Quantitative and qualitative analysis of the knowledge, attitudes and social representations of cholera in the extreme northern region of Cameroon: the case of Maroua I, Maroua Ii and Mokolo. Pan Afr Med J. 2014;17:1-6. doi:10.11604/pamj.2014.17.253.2799

15. Veronicaa MM, Kagoma SM. Knowledge, attitudes and practices regrading cholera outbreaks in ilala municipality of dar es salaam region, tanznia. East Afr J Public Health. 2005;2(2):6-11.

16. Ilesanmi O, Alele FO. Knowledge, attitude and perception of ebola virus disease among Secondary School Students in Ondo State, Nigeria, October, 2014. PLoS Curr. 2016. doi:10.1371/currents.outbreaks.c04b88cd5cd03cccb99e125657eecd76

17. Prati G, Pietrantoni L. Knowledge, risk perceptions, and xenophobic attitudes: evidence from Italy during the ebola outbreak. Risk Anal. 2016;36(10):2000-2010. doi:10.1111/risa.12537

18. Yap J, Lee VJ, Yau TY, Ng TP, Tor P. Knowledge, attitudes and practices towards pandemic influenza among cases, close contacts, and healthcare workers in tropical Singapore: a cross-sectional survey. BMC Public Health. 2010;10(1):442. doi:10.1186/1471-2458-10-442 
19. Klaiman T, Kraemer JD, Stoto MA. Variability in school closure decisions in response to $2009 \mathrm{H} 1 \mathrm{~N} 1$ : a qualitative systems improvement analysis. BMC Public Health. 2011;11(1):73. doi:10.1186/1471-2458-11-73

20. Otekunrin OA, Ayinde IA, Otekunrin OA, De Campos JS. Effect of avian influenza on household consumption of poultry products: evidence from first outbreak in Ogun State, Nigeria. Curr Agric Res J. 2018;6(3):328-336. doi:10.12944/CARJ.6.3.11

21. Dkhar S, Quansar R, Saleem S, Khan SMS. Knowledge, attitude, and practices related to COVID-19 pandemic among social media users in J\&K, India. Indian J Public Health. 2020;64(6):205. doi:10.4103/ ijph.IJPH 46920

22. Akan H, Gurol Y, Izbirak G, et al. Knowledge and attitudes of university students toward pandemic influenza: a cross-sectional study from Turkey. BMC Public Health. 2010;10(1):413. doi:10.1186/1471-2458-10-413

23. Nyland C, Forbes-Mewett H, Marginson S. The international student safety debate: moving beyond denial. High Educ Res Dev. 2010;29 (1):89-101. doi:10.1080/07294360903277364

24. Song G, Liu L, He S, Cai L, Xu C. Safety perceptions among African migrants in Guangzhou and Foshan, China. Cities. 2020;99:102624. doi:10.1016/j.cities.2020.102624

25. Wei G, Lin W, Jingdong Y, Yanxiong W. China as a global destination for international students. J Polit Law. 2020;13(1):135. doi:10.5539/jpl.v13n1p135

26. Latief R, Lefen L. Analysis of Chinese government scholarship for international students using analytical hierarchy process (AHP). Sustainability. 2018;10(7):2112. doi:10.3390/su10072112

27. Bovenkamp van de J, Fei Y. Economic overview of hubei province economic overview. 2016:1-19.

28. Moe.gov.cn. Statistical report on international students in China for 2018 Ministry of Education of the People's Republic of China. moe.gov.cn; Published 2020. Available from: http://en.moe.gov.cn/documents/reports/ 201904/t20190418_378692.html. Accessed May 11, 2020.

29. Israel GD. Using published tables using formulas to calculate a sample size using a census for small populations.

30. Srichan P, Apidechkul T, Tamornpark R, et al. Knowledge, attitude and preparedness to respond to the 2019 novel coronavirus (COVID-19) among the bordered population of Northern Thailand in the early period of the outbreak: a cross-sectional study. Available SSRN 3546046. 2020.

31. Zhong B-L, Luo W, Li H-M, et al. Knowledge, attitudes, and practices towards COVID-19 among Chinese residents during the rapid rise period of the COVID-19 outbreak: a quick online cross-sectional survey. Int J Biol Sci. 2020;16(10):1745-1752. doi:10.7150/ijbs.45221
32. Ngwewondo A, Nkengazong L, Ambe LA, et al. Knowledge, attitudes, practices of/towards COVID 19 preventive measures and symptoms: a cross-sectional study during the exponential rise of the outbreak in Cameroon. PLoS Negl Trop Dis. 2020;14(9):e0008700. doi:10.1371/journal.pntd.0008700

33. Bates BR, Moncayo AL, Costales JA, Herrera-Cespedes CA, Grijalva MJ. Knowledge, attitudes, and practices towards COVID-19 among ecuadorians during the outbreak: an online cross-sectional survey. J Community Health. 2020;45(6):1158-1167. doi:10.1007/s10900-020-00916-7

34. Training A-D. China - outbound and inbound international students. 2016.

35. Li D, Huang L, Yang W, et al. Knowledge, attitude and practice level of women at the periconceptional period: a cross-sectional study in Shaanxi China. BMC Pregnancy Childbirth. 2019;19(1):326. doi:10.1186/s12884-019-2481-6

36. Ejeh FE, Saidu AS, Owoicho S, et al. Knowledge, attitude, and practice among healthcare workers towards COVID-19 outbreak in Nigeria. Heliyon. 2020;6(11):e05557. doi:10.1016/j.heliyon.2020.e05557

37. Yang K, Liu H, Ma L, et al. Knowledge, attitude and practice of residents in the prevention and control of COVID-19: an online questionnaire survey. J Adv Nurs. 2020:14718. doi: 10.1111/jan.14718.

38. Haftom M, Petrucka P, Gemechu K, et al. Knowledge, attitudes, and practices towards COVID-19 pandemic among quarantined adults in Tigrai Region, Ethiopia. Infect Drug Resist. 2020;13:3727-3737. doi:10.2147/IDR.S275744

39. Wong CL, Chen J, Chow KM, et al. Knowledge, attitudes and practices towards COVID-19 amongst ethnic minorities in Hong Kong. Int $J$ Environ Res Public Health. 2020;17(21):7878. doi:10.3390/ijerph17217878

40. Parajuli J, Mishra P, Sharma S, et al. Knowledge and attitude about COVID 19 among health care workers working in seti provincial hospital. J Nepal Health Res Counc. 2020;18(3):466-471. doi:10.33314/jnhrc.v18i3.2816

41. Nauja RH, Bugoye FC, Rongo LMB. Knowledge, perceptions and practices on cholera transmission and prevention measures among heads of household members in Kigamboni municipality, Dar Es Salaam, Tanzania. Int J Res. 2019;7:28-48. doi:10.5281/zenodo.3556864
Infection and Drug Resistance

\section{Publish your work in this journal}

Infection and Drug Resistance is an international, peer-reviewed openaccess journal that focuses on the optimal treatment of infection (bacterial, fungal and viral) and the development and institution of preventive strategies to minimize the development and spread of resistance. The journal is specifically concerned with the epidemiology of antibiotic resistance and the mechanisms of resistance development and diffusion in both hospitals and the community. The manuscript management system is completely online and includes a very quick and fair peerreview system, which is all easy to use. Visit http://www.dovepress.com/ testimonials.php to read real quotes from published authors. 